\title{
Assessment of Infection Control Standards in a Tertiary Healthcare Facility in Tribal Region of West Maharashtra, Central India
}

\author{
Author \\ Dr Vandana Agarwal \\ Professor \& Head, Department of Microbiology, Government Medical College and Hospital, Chandrapur, \\ Maharashtra, India \\ Corresponding Author \\ Dr Vandana Agarwal \\ Email:agarwal.gmc@gmail.com
}

\begin{abstract}
A total of 11 infection control standards were assessed in a tertiary healthcare facility in a tribal region of Maharashtra. The aim was to identify areas with scope of improvement and suggest remedial measures to minimize the risk of hospital-acquired infection. Out of the 11 standards, the rate of surgical site infections was $2.24 \%$, while deficiency was observed in 3 standards. The total score was 10.5 on a 12-point scale, a satisfactory score. A strictly professional nursing care together with efficient administrative contribution helped in achieving a high score.
\end{abstract}

\section{Introduction}

Over 1.5 million people worldwide are reported to be suffering from hospital-acquired infections (HAI). These are a significant cause of morbidity and mortality. One third of all such episodes are potentially preventable.

The present study has focussed on capturing 11 standards that are needed to prevent hospitalacquired infections. The purpose of the study was to assess these standards and suggest remedial measures so as to minimize the risk of HAI in our healthcare facility.

\section{Materials and Methods}

\section{Infrastructure}

The study was conducted in a 300-bedded functional tertiary care teaching health facility in a tribal region of Maharashtra in Central India. The healthcare setting has 13 clinical departments with in-patient and out-patient facility, 3 operation theatres (OT), an intensive care unit (ICU), a special neonatal care unit (SNCU), labour room (LR), dialysis unit casualty department, central clinical laboratory, central research laboratory, central hospital pharmacy and stores, central kitchen, linen section, central library, medical record section and a biomedical waste collection centre.

\section{Pre-assessment training programmes.}

i. Exhaustive training of medical and paramedical staff was undertaken for 3 months.

ii. CME on "Infection Control Measures" and "Rational Use of Antimicrobials"were conducted for medical and paramedical staff.

iii. Nursing staff was trained on maintaining records on infection control standards and identification of indicators of HAI.

iv. Demonstrations were made on safe hospital practices during regular surveillance to paramedical staff including safai karamcharis. 
v. Guidelines for biomedical waste (2016) were circulatedto heads of all departments, Medical Superintendent, Matron and Sanitary Inspector.

vi. Nursing staff was deputed to regional centre for "Training of trainers on newer concepts of biomedical waste management."

vii. Meetings of Hospital Infection Control Committee played an important role in disseminating lapses in infection control measures and suggesting corrective actions
Assessment of infection control standards

A total of 11 standards were assessed as per criteria laid down by National Accreditation Board for Hospitals and Healthcare Providers ${ }^{[1]}$. The expected norm for each standard was predefined (Table 1). Based upon the observed value, each standard was scored on a scale of 12 points; the contributory weightageof infection control standards for accreditation of a healthcare facilitybeing $12 \%$.

\section{Results}

The results obtained are shown in Table 1.

Table 1: Assessment of Infection Control Standards

\begin{tabular}{|c|c|c|c|c|c|}
\hline $\begin{array}{l}\text { Sr. } \\
\text { No. }\end{array}$ & Standard & Expected Norm & Observation & $\begin{array}{l}\text { Maximum } \\
\text { Score }\end{array}$ & $\begin{array}{l}\text { Observed } \\
\text { Score }\end{array}$ \\
\hline 1. & $\begin{array}{l}\text { Air quality monitoring } \\
\text { [2] }\end{array}$ & $\begin{array}{l}\text { - Number of air samples } \\
\text { contaminated per } 100 \text { air samples } \\
\text { tested must be zero } \\
\text { - Maintenance of records }\end{array}$ & $\begin{array}{ll}- & \text { Procedure for aerial disinfection by } \\
\text { fogging/ fumigation was satisfactory } \\
\text { - } & \text { No air contamination observed in } \\
\text { OT/ ICU/ SNCU/ LR } \\
\text { - } & \text { Records well maintained }\end{array}$ & 1 & 1 \\
\hline 2. & $\begin{array}{l}\text { Functioning of } \\
\text { Infection Control } \\
\text { Committees [2] }\end{array}$ & $\begin{array}{ll}\text { - } & \mathrm{HICC}^{1}: 3 \text { monthly meetings } \\
\text { - } & \mathrm{HTMC}^{2}: \text { monthly meetings } \\
\text { - } & \mathrm{TMC}^{3}: \text { weekly meetings } \\
\text { Records of minutes of meetings }\end{array}$ & $\begin{array}{l}\text { - HICC functioned satisfactorily\& } \\
\text { minutes of meetings were recorded } \\
\text { - No records of minutes of meetings of } \\
\text { HTMC and TMC were available }\end{array}$ & 1 & 0.5 \\
\hline 4. & $\begin{array}{l}\text { Ventilator Associated } \\
\text { Pneumonia (VAP) }\end{array}$ & $\begin{array}{ll}\text { - } & \text { Number of VAPs per } 1000 \\
\text { ventilator days should be } \leq 5 \% \\
\text { - }\end{array}$ & $\begin{array}{l}\text { - No case of VAP was reported from } \\
\text { ICU/ SNCU } \\
\text { - } \quad \text { Records were maintained }\end{array}$ & 2 & 2 \\
\hline 7. & $\begin{array}{l}\text { Hand hygiene } \\
\text { guidelines }\end{array}$ & $\begin{array}{l}\text { Posters on hand hygiene guidelines } \\
\text { at all workstations } \\
\text { - Availability of soap (cakes \& } \\
\text { liquid), alcoholic handrub, wiping } \\
\text { towels/ dryers } \\
\text { - Basin fitted with elbow-cork taps } \\
\text { and continuous water supply }\end{array}$ & $\begin{array}{l}\text { - Hand hygiene guidelines followed } \\
\text { All accessories for handwash } \\
\text { available except taps with elbow-cork }\end{array}$ & 0.5 & 0.5 \\
\hline 8. & $\begin{array}{l}\text { Central Sterilization \& } \\
\text { Supply Department } \\
\text { (CSSD) }\end{array}$ & $\begin{array}{l}\text { Autoclave records with exposed } \\
\text { chemical indicator strips for } \\
\text { sterility testing }\end{array}$ & $\begin{array}{l}\text { - } \quad \text { Records available and satisfactory } \\
\text { Indicator strips were pasted on the } \\
\text { register }\end{array}$ & 1 & 1 \\
\hline \multirow[t]{2}{*}{11.} & $\begin{array}{l}\text { Hospital Antibiotic } \\
\text { Policy }\end{array}$ & $\begin{array}{l}\text { - Formulation \& implementation of } \\
\text { Hospital Antibiotic Policy }\end{array}$ & - $\quad$ Not available & 0.5 & 0 \\
\hline & & & TOTAL & 12 & 10.5 \\
\hline
\end{tabular}




\section{Discussion}

Hospital infection control standards contribute $12 \%$ weightage for accreditation of a healthcare facility ${ }^{[1]}$. A critical assessment of all the infection control standards showed that our tertiary healthcare facility scored a total of 10.5 points on a 12-point scale. This indicates that the protocol for infection control followed in the healthcare facility was satisfactory. A strictly professional nursing care together with the efficient administrative contribution have helped in achieving a score of 10.5 .

The rate of SSI was $2.24 \%$ (Table 1, standard 3). Though the figures were within the limits of acceptability, the policy of pre-operative skin preparationwas changed from using $5 \%$ betadine to the use of $10 \%$ betadine. A one month followup showed the change to be effective.

Deficiencies were observed in 3 out of 11 standards. Firstly, assessment of functioning of Infection Control Committees showed that HICC functioned with regularity documenting minutes of meeting. However, HTMC and TMC meetings were irregular with no documentation of minutes of meeting. Significance of HTMC and TMC meetingswere explained to the committee members and reinforced during HICC rounds.

Secondly, prophylaxis with Hepatitis B vaccine to high risk HCP was not implemented as government supply of Hep B vaccine was not available. Instructions were given to the store incharge by Chairman HICC for procuring Hep B vaccine for high risk HCP.

Thirdly, hospital antibiotic policy was not formulated. A CME was conducted on current trends on rational use of antibiotics. As the hospital was only recently upgraded to a tertiary care hospital from a secondary care hospital, atleast one year was required to generate sufficient laboratory data on antimicrobial resistance. Subsequently, it is expected that the hospital antibiotic policy will be formulated.

\section{Conclusion}

The study has shown that currently infection control standards were being practised satisfactorily in our healthcare facility. Surveillance should continue with same zeal and with regular training programmes/ workshops/ demonstrations for both medical and paramedical staff. In addition, staff should be deputed from time to time for attending infection control activities wherever possible.

\section{References}

1. National Accreditation Board for Hospitals and Healthcare Providers: Course material for Training program on empanelment criteria under Rajiv Gandhi Jeevandayee Arogya Yojana; Issue Feb. 2014.

2. Directorate of Medical Education and Research: Recommendations of state-level subcommittee of infection control committee regarding specific operational procedures for the operation theatre management; Issue $9^{\text {th }}$ Feb. 2000

3. Ministry of Environment, Forest and Climate Change, Government of India: Biomedical-waste Management Rules, notification dated $28^{\text {th }}$ March 2016. 